\title{
LEAN MANUFACTURING IMPLEMENTATION IN INVENTORY CONTROL AS A REPAIR PROCESS
}

\author{
Fino Wahyudi Abdul \\ Dosen Institut Ilmu Sosial dan Manajemen STIAMI \\ Email : finowahyudi71@gmail.com
}

\begin{tabular}{ll}
\hline ARTICLE INFO & ABSTRACT \\
\hline Keywords: & This control study was carried out at the PT AW Printing Company which had quite a \\
lean, & number of problems that were often used from its store. The approach is action \\
persediaan. & research with a focus on distributing and storing raw materials for lean manufacturing. \\
& The analysis is production staff who need a lot of excess paper that can still be used, \\
& and use too much paper in print production. The company then enforces a new \\
& procedure that is not possible to get printouts that can still be used using the principle \\
& of 7 waste, to use those that cannot be used. Scope of study for the process of \\
& distribution, selection and use of raw materials, understanding the meaning of supply \\
& preparation (logistics) by employees and delivery of finished products. The results of \\
& the study show that product delivery is low to customers because of the low inventory \\
& turnover. In the PT XY preparation division, there are approximately 80\% of which \\
& have potential factors. The contributing factors are long demand for goods, unclear \\
forecasting, not understood standards for demand, inaccurate recording, vital factors \\
affecting raw materials is the selection and use of raw materials.
\end{tabular}

\section{PENDAHULUAN}

Inventories are fundamental in determining long-term competitive advantage. Quality, engineering, product, price, overtime, over capacity, ability to respond to customers due to poor performance, lead time and overall profitability are things that are affected by inventory levels. Companies with higher inventory levels than competitors tend to be in a strong competitive position. Inventory management policy has become a weapon for winning competition.

In supply chain management activities, logistics supply issues have an important role because the problems in the production section depend on the supply of raw materials that are always available. If production is disrupted, the delivery of goods to customers is also disrupted which results in customers (customers) being disappointed because the company does not maintain the quality of its services. This research was conducted to identify which parts of the non value added were considered as waste. Thus improvements can be made that not only provide better quality of service through the delivery period of equipment and materials to the customer's location, but also cost emphasis that can provide more competitive prices to prospective customers. 
In manufacturing companies, inventory consists of inventories of raw materials, goods in process and finished goods inventory. The inventory that will be examined here is more focused on controlling the supply of printed paper raw materials. The control of raw material inventories aims to make the level of raw material inventory sufficient, not too much but not too little, so that the cost of raw materials becomes economical and the company does not lose the opportunity to serve sales due to lack of raw material supply.

The development of information technology and customer demands are increasingly high. The current competition is no longer a competition between companies but it is competition between supply chain networks. Supply chain is a part that plays an important role in every company that wants to win the competition, so that the supply chain plays an important role in the supply to the world of industry, both manufacturing and services.

Today's business competition is getting tighter along with the increasingly global market, the development of information technology and increasingly high customer demands, especially in the industrial sector in the face of changing and increasingly difficult challenges from time to time. Current business competition is no longer a competition between companies but competition between supply chain networks.

Supply chain is a network of companies that work together to create and deliver a product to the end user. These companies usually include suppliers, distributor factories, stores, retailers, and supporting companies such as logistics service companies. The supply chain is the part that plays an important role in every company that wants to win the competition. Therefore there must be an assessment of the supply chain performance in each year so that there is continuous improvement in the supply chain flow in the company. With effective performance measurement, it will be able to express what adjustments are needed in the flow of the company's supply chain. Performance measurement in the supply chain involves internal processes and also the expected performance of other supply chain member companies. With the back chain are suppliers and front chains are customers. The quality revolution in the late 1980s and the supply chain revolution in the early 1990s made it clear that companies that wanted to win the competition needed to integrate environmental management with continuous operational activities. In addition, global market demand and government pressure to encourage businesses to become more sustainable (Womack, et al, 1990).

\section{METODOLOGI}

Inventory management is fundamental in determining long-term competitive advantage. Quality, engineering, product, price, overtime, over capacity, ability to respond to customers due to poor performance, lead time and overall profitability are things that are affected by inventory levels. Companies with higher inventory levels than competitors tend to be in a weak competitive position. Inventory management policy has become a weapon for winning competition (Zulfikarijah, 2005).

In manufacturing companies, inventory consists of inventories of raw materials, goods in process and finished goods inventory. Inventory management which will be discussed here is more focused on the 
management of raw material inventories. The management of raw material inventories aims to make the raw material inventory level sufficient, not too much but not too little, so that the cost of raw materials is economical and the company does not lose the opportunity to serve sales due to lack of raw material supplies.

Supply chain management, suggests that time is used as a metric in performance measurement because time control and shortening can improve quality, reduce costs and improve responsiveness to customer needs and productivity.

Lean is defined as a process that consists of five steps: defining values for customers, establishing value streams, making them "flow", "being pulled" by customers, and striving to achieve the best. The thought of streamlining in supply chain management is the use of lean principles in different functions within the company to manage good business relationships between consumers and their suppliers / contractors. The lean principles and tools for processing are shown in Table 1.

Table 1. Lean principles and tools

\begin{tabular}{|l|l|}
\hline Principles & Tools \\
\hline Waste reduction & $\begin{array}{l}\text { Value stream mapping, problem } \\
\text { solving, five } \\
\text { why's }\end{array}$ \\
\hline Just-In-Time & $\begin{array}{l}\text { Pull system, fast change, one-piece } \\
\text { and continuous flow, Kanban, } \\
\text { heijuka, taktime planning }\end{array}$ \\
\hline $\begin{array}{l}\text { Jidoka/ Make } \\
\text { problems visible }\end{array}$ & $\begin{array}{l}\text { Visual tools, 5S, Poka } \\
\text { Yoka (error proofing) }\end{array}$ \\
\hline Single market quality & $\begin{array}{l}\text { Stabilization and standardization } \\
\text { process. }\end{array}$ \\
\hline $\begin{array}{l}\text { Continous } \\
\text { Improvement }\end{array}$ & $\begin{array}{l}\text { Kaizen (pay attention to waste and } \\
\text { daily repairs), Disiplin }\end{array}$ \\
\hline $\begin{array}{l}\text { Respect } \\
\text { People }\end{array}$ & $\begin{array}{l}\text { Security, work team, training, } \\
\text { reward distribution }\end{array}$ \\
\hline
\end{tabular}

Value Stream Mapping is one method to map process flow and information flow to produce one product or service, not only in each work area and identify activities that value added and non value added. Waste is defined as an activity that does not add to the final product. Value stream mapping is a communication tool, 
which is used as a strategy planning tool and as a management change tool. Waste is an element of a process that does not add added value to a result of the process. Waste only adds costs and time, this is a major problem in the system (in the process and value stream level).

With lean companies can get the speed that lean has in the production process (Laureani, 2012). Lean grows from the concept of "just in time" and "Toyota Production System" by eliminating waste and focusing on customers (Debits \& Debuks, 2010).

Lean management defines the company's goals towards customer value, designs and implements the value of the flow and the right process to achieve its goals, aligning the process to people who are in touch in solving problems and this lean method has been developed by Toyota to help standardize continuous improvement (known with the Toyota Production System / TPS) (Jayaraman, 2010). Gaspersz (2007) lean can be defined as a systemic approach to identify and eliminate waste, streamline material, product and information flows and continuous improvement. Liker (2006) TPS identifies seven types of waste (7 waste) that do not add value, namely overproduction, waiting, transportation, overprocessing, inventory, motion and defects.

\section{ANALISA DAN PEMBAHASAN}

Print Paper Inventory Check Results Data for 2016, for 52 weeks, in Table 2.

Table 2. (Print paper inventory inspection results)

\begin{tabular}{|l|l|l|}
\hline Week & Inventory Need $(\mathrm{Kg})$ & Available Inventory $(\mathrm{Kg})$ \\
\hline 52 & 50.000 & 600 \\
\hline
\end{tabular}

\section{Define}

Problems that arise are obtained from the voice of the customer (voice of customer), namely the inventory department, which complains that the supply of printing paper is always reduced. This results in the production process being hampered and end users often late getting the prints they ordered. The management of the company wants an increase in the timeliness of production and the delivery of printouts.

The analysis is that production staff often dispose of excess paper left over from prints that should still be usable, and use too much paper in print production. The company then applies a new procedure that is not allowed to dispose of the remaining printed paper that can still be used with the lean method for efficient use so that the rest of the paper can be used.

The purpose of this stage is to find out the cause of the most important waste based on the lean method approach with the application of 7 waste, namely waiting, unnecessary inventory, defects, unnecessary motion, over production, transportation and unnecessary activities. From the Pareto diagram in Figure 1, the 
potential factor is in waiting and unnecessary inventory which has the greatest influence on the printing paper supply.

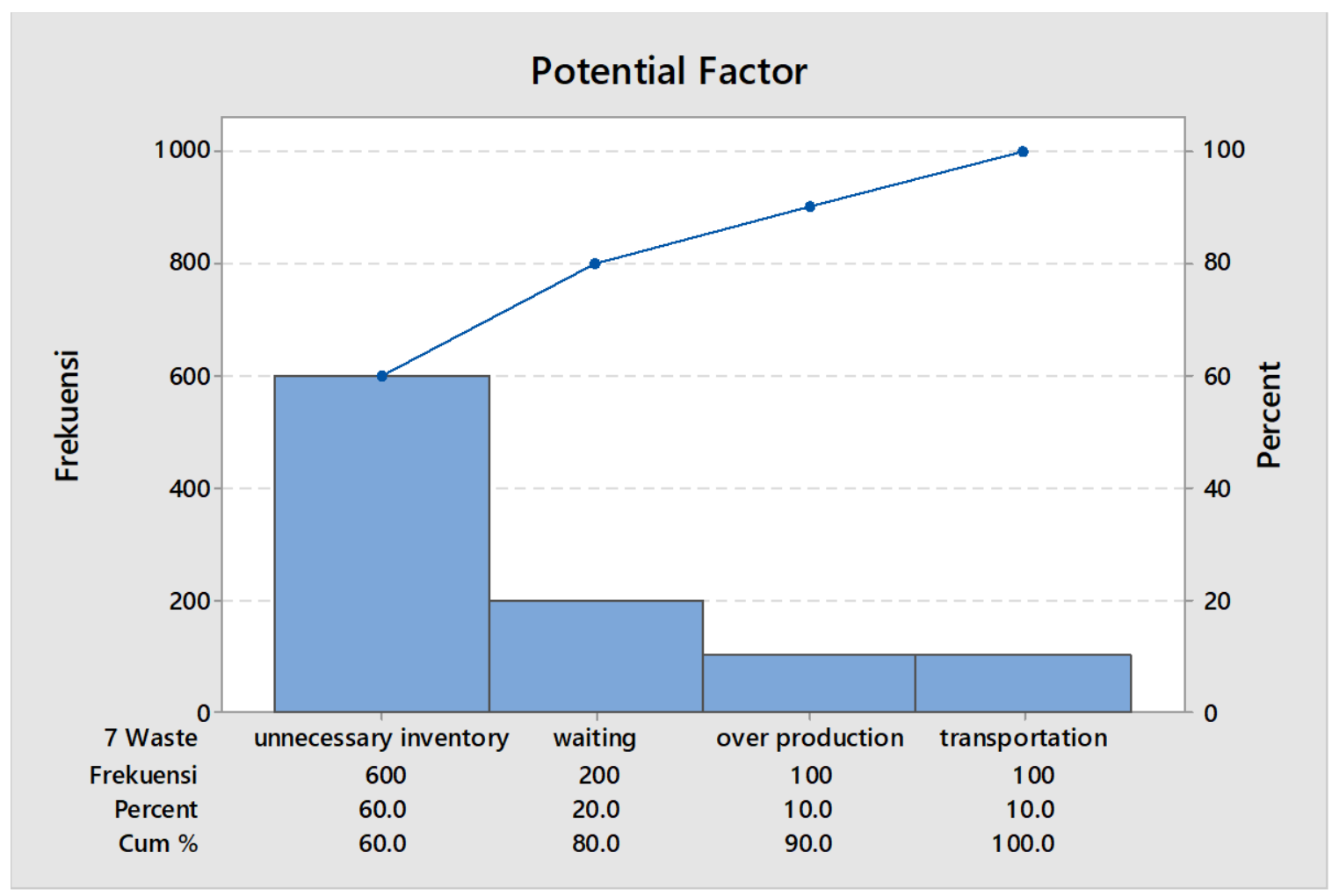

\section{Measurement}

Gambar 1. Diagram pareto

Potential factor based on 7 waste includes the process of sending 200 (waiting) prints, selection and use of paper (unnecessary inventory) 600, printing on paper (over production) 100, understanding the meaning of supply supplies (logistics) by PT AW employees and distribution (transportation) 100. The results of the study indicate that the low delivery of printouts to customers is due to low inventory turnover, in the selection and use of paper. Based on analysis of pareto diagrams related to waiting and unnecessary inventory, the vital factors that influence the printing paper inventory are the selection and use of paper.

\section{Improvement}

In the improvement stage, improvements are made to the lean methodology based on the 7 waste approach, which is needed to see if there are steps to the process that do not need to be done, which is a waste in 7 waste. Based on 7 waste, there is an unnecessary inventory, namely the selection and use of paper.

Based on the results of the analysis at analyze phase, it is necessary to improve the time to complete the analysis by replacing laboratory equipment that is damaged due to leakage and tightening the SOP (standard operational procedure) for the use of laboratory equipment for employees of the analysis. 


\section{CONCLUSION}

The conclusion is that production staff often dispose of excess paper left over from prints that should still be able to be used, and use too much paper in print production. The company then applies a new procedure that is not allowed to dispose of the remaining printed paper that can still be used with the lean method for efficient use so that the rest of the paper can be used. Then the six sigma method is used to see the level of quality based on sigma level values. As a result, the amount of printed paper wasted reduced by $40 \%$ with an estimated profit of Rp. $15 \mathrm{M}$.

\section{REFERENCES}

Debusk, G., K. \& Debusk, C. (2010). "Characteristics of Successful Lean Six Sigma Organizations”. Cost Management, 24 (1) : 5-10.

Jayaraman, K. (2010). Value Stream Mapping-Adapting Lean Management Principle in the ESO. Integrated Engineering Service (IES). Retrieved from http://www.inttechservices.com/media/28549/valuestream-mapping-adapting-lean-Management-principle-in-the-eso.pdf.

Liker, J., K. (2006). The Toyota Way 14 Prinsip Manajemen dari Perusahaan Manufaktur Terhebat di Dunia, Jakarta, Penerbit Erlangga.

Laureani, A. (2012). Lean Six Sigma in Service Industry. Advanced Topics in Applied Operations Management. Retrieved from http://www.intechopen.com/books/advanced-Topics-in-appliedoperations-management/lean-six-sigma-in-theservice-industry.

Gaspersz, V. (2007). Lean Six Sigma for Manufacturing and Service Industries. Cetakan Keempat, Jakarta, PT. Grademia Pustaka Utama.

Womack, J., Jones, D.T. and Roos, D. (1990), The Machine that Changed the World, Macmillan, New York, NY.

Zulfikarijah, F. 2005. Manajemen Persediaan. Malang: Universitas Muhammadiyah. 